\title{
Supply Chain Risk Mapping and Analysis: A FMEA Implementation on Biofuel Downstream Supply Chain
}

\author{
Tedy Wachyudi ${ }^{1, *}$, Arief Daryanto ${ }^{2}$, Mahfud $^{2}$, Yandra Arkeman ${ }^{2}$ \\ ${ }^{1}$ Doctoral Student at School of Business, Institut Pertanian Bogor \\ Indonesia \\ ${ }^{2}$ Lecturer at School of Business, Institut Pertanian Bogor \\ Indonesia \\ *Corresponding author's email: mytedyw [AT] gmail.com
}

\begin{abstract}
The domestic biofuel program of Indonesia has been facing number of dynamics and challenges, such as: low production, uncertainty of feedstock availability, low realized consumption, price fluctuation and less competitive, unfit and viewer infrastructure, imbalance distribution. This study aims to map and analyze supply chain risks of biodiesel downstream business and offers a practical implementation of Failure Mode and Effect Analysis (FMEA) in the supply chain risk analysis. It employs a qualitative approach. A semi-structured surveys and interviews applied in data collection. The research level of analysis is at corporate level. The study result shows that there are three highest risks arise related to regulation related risk, product arrival (delays) risk and transportation facilities risk with the Risk Priority Number (RPN) of 72 to 48 and the Risk Score Value (RSV) of 24 to 16. The result also shows that there is correlation between stakeholder types, locations and levels of information with their perception of biodiesel supply chain risk and risk priorities. The result may become a valuable input for developing such risk mitigation strategy to improve and enhance the effectivity and the sustainability of supply chain in both the company and the biodiesel industry.
\end{abstract}

Keywords--- supply chain, risk mapping and analysis, biofuel, failure mode and effect analysis

\section{BACKGROUND}

Supply chain risk management has been putting itself on a critical and strategic role within a business perspective (Anggara 2009; Ghadge et al. 2012; Peng et al. 2014). Business and its supply chain risk management dynamics has been facing some phenomenon of volatility, uncertainty, complexity, ambiguity (V.U.C.A) which have been arising (Packowski 2014; Mack et al. 2016; Nadram dan Bindlish 2017). One of V.U.C.A phenomenon has also been facing by the Indonesian biofuel industry. The Indonesia domestic biofuel program has been facing number of dynamics and challenges, such as: low production, uncertainty of feedstock availability, low realized consumption, price fluctuation and less competitive, unfit and viewer infrastructure, imbalance distribution (Aprobi 2016; ESDM 2015; BPDPKS 2016). The supply chain management team looks for strategy to minimize impacts of existing disruptions (Bowman 2015).

The study applies Failure Mode and Effect Analysis as a tool of analysis. It has several benefits, simpler usages, and capability to identify potential failures and their mitigation planning. It also has a systematical overview over system failure (Aven 2015). The stakeholder theory also applied in this study. Based on the literature review of supply chain risk management there were several gaps arise. The gaps include the context of risk and risk management definition, strategy and process (Juttner et al. 2003; Juttner 2005; Manuj \& Mentzer 2008).

This study covers the biodiesel downstream supply chain, included the activities of supply, process and demand of retail biodiesel. The research takes place at Supply \& Distribution Region III PT Pertamina (Persero) which covers the following three main areas of: Jakarta (the capital of Indonesia), West Java Province and Banten Province. There are number of reasons and considerations to choose the mentioned research areas, such as: its location strategical aspect, its commercial and market complexity aspect, and its operational complexity aspect. The research focuses on the study of retail biodiesel supply chain risks in the downstream operation perspective.

There only a viewer study of risk management based for biofuel supply chain researches. The study of its risk management context mostly focused on probability and impact aspects of the risks. The existence of a more holistic view and study of the mentioned risk management are still limited. This study will propose novelties. The first is a biodiesel supply chain areas of activities-based risk map. The second is a multi-level view of stakeholders -based biodiesel supply chain risk map. The third is biodiesel risk mitigation strategy alternatives. 


\section{METHODOLOGY}

Descriptive and explanatory approach applies in this research. Descriptive approach includes number of literature studies and secondary data analysis. Explanatory approach includes number of expert surveys and interviews.

Research boundary of the study includes the activities of downstream biodiesel supply chain at PT Pertamina (Persero). It is an Indonesian state-owned enterprise which focused in energy business, especially in oil and gas businesses, which in this paper will stated as Pertamina or company. The research takes place at Pertamina Supply \& Distribution Region III, including the areas of: Jakarta as the capital of Indonesia, West Java Province and Banten Province. The period of research was from June 2018 until November 2018, including the research activities of: research preparing, data collecting, data processing and analyzing, and reporting the result. All of these activities conducted in Indonesia.

There are two types of data collected, including primary and secondary data. Sources of data are from both internal and external of the company. Table 1 shows list of the research steps, data sources and data collection methods). The data collects through observations, surveys and interviews (depth-interviews).

Table 1 Research steps, data sources and methods

\begin{tabular}{cllc}
\hline No. & \multicolumn{1}{c}{ Steps } & Data Sources & Methods \\
\hline 1 & Identify risk events & Company's primary \& secondary data & Interviews, FMEA \\
2 & Determine probability, severity, detection & Company's primary \& secondary data & Interviews, FMEA \\
3 & Calculate risk scores (RPN, RSV) & Company's primary \& secondary data & FMEA \\
4 & Result analysis & Company's primary \& secondary data & FMEA \\
5 & Result validation & Company's primary \& secondary data & Interviews, FMEA \\
\hline
\end{tabular}

Table 2 Interviewed experts list

\begin{tabular}{clllc}
\hline No. & \multicolumn{1}{c}{ Expert Levels } & \multicolumn{1}{c}{ Positions } & \multicolumn{1}{c}{ Locations } & $\begin{array}{c}\text { Year of } \\
\text { Experiences }\end{array}$ \\
\hline 1 & Visionary Leader & Director & LSI Directorate, H.O. Jakarta & $>25$ \\
2 & Strategic Leader & Vice President & S\&D Division, H.O. Jakarta & $>25$ \\
3 & Operation Leader & Region Manager & S\&D Region III, Jakarta & $>25$ \\
4 & Operation Leader & Operation Head & Fuel Terminal 1 + 2 (Group), Jakarta & $>15$ \\
5 & Operation Leader & Operation Head & Fuel Terminal 3, Cilegon - Banten & $>20$ \\
6 & Operation Leader & Operation Head & Fuel Terminal 4, Indramayu - West Java & $>15$ \\
7 & Operation Leader & Operation Head & Fuel Terminal 5, Cikampek - West Java & $>20$ \\
8 & Operation Leader & Operation Head & Fuel Terminal 6 + 7 (Group), Bandung - West Java & $>20$ \\
9 & Operation Leader & Operation Head & Fuel Terminal 8, Tasikmalaya - West Java & $>20$ \\
\hline Source: & Author (2018) & & &
\end{tabular}

Table 2 includes the list of surveyed and interviewed experts of the company supply chain. The experts must fulfill their qualifications of expertise, legitimation and access to the supply chain policies and activities. Semi-structured questionnaire takes place in applying surveys and interviews to the respondents and interviewees. The level of analysis is at corporate level.

This research employs FMEA method. The method used for identifying, mapping and analyzing the supply chain risk management of biodiesel within the target company. It combines with the application of a semi-structured surveys and interviews. A multiple-methods is commonly used in a case study. It has different steps. The first, is collecting data by using semi-structured surveys and interviews. The next step is analyzing the collected data by using the FMEA. It also includes the activities of identifying and assessing the related risks.

Basically, the process of FMEA consists of: risk identification, risk assessment and risk mitigation plan. Risk Priority Number (RPN) and Risk Score Value (RSV) are calculated to evaluate potential risks. The calculation involves: occurrence, severity and detection as key factors of risk. 


\section{RESULT AND DISCUSSION}

This part of paper describes a list of results and findings of the research. Those includes the discussion of the target company's biodiesel supply chain business process, related risk mapping and risk analyzing.

\section{Company's downstream supply chain network of biodiesel}

For servicing domestic market customers, Pertamina's downstream fuel supply chain activities involved at least 109 fuel terminal (depot) units with the total fuel storage capacity of 5.5 million kilo liters and the fuel throughput of 85 million kilo liters per year. The fuel storages spreads among 8 fuel supply and distribution regions which covers 5 big islands (Sumatera, Jawa, Kalimantan, Sulawesi and Papua) and hundreds up to thousands smaller islands surround. The activities involved a large amount of infrastructure facilities for servicing both cities and remote areas where customers exist.

In the context of this research boundary, within the Pertamina fuel supply and distribution region III context, the supply chain activities involved: 8 fuel terminal units which involves 139 units of fuel storage tanks with the total fuel storage tanks capacity of 1.5 million kilo liters and the fuel throughput of 15.5 million kilo liters per year. The activities also involved at least 600 units of fuel tank truck, 15 units of vessel, and 960 kilo meters line-pipe facilities. The activities service covers at least 2.332 retail customers (fuel station units) fuel station units, 336 industrial customers and 169 special customers (such as government institutions).

The application of biodiesel mandatory in Indonesia domestic market starts in 2006. There were such dynamics and progress arise along the periods of 2006 up to know. Those involved such dynamics of opportunities and threats or risks within, including in biodiesel supply chain activities.

The company's biodiesel supply chain network describes in Figure 1. It consists of three main areas of: supply, process and demand. The first areas include Fatty Acid Methyl Esther (FAME) supply and diesel fuel supply areas. FAME supplied by FAME producers and or FAME suppliers from the company's external. Diesel fuel supplied by diesel fuel producers and or suppliers from the company's internal (the company owned fuel refineries) and or the company's external (import). The second areas include such activities of FAME and diesel fuel receiving, storaging, blending, product handling and distributing at the company's main-fuel depot and end-fuel depot. The third areas include such activities of biodiesel product receiving, storaging, handling and using by customers. Finally, those related data of product supply and distribution activities will be derived as valuable feedback for the next biodiesel supply chain activities. At fuel depot units the blending process takes place. Figure 1, 2 and 3 describes the flow of process of the target company's biodiesel downstream supply chain. The blending process are almost similar among fuel terminals with a certain process variation and combination within.

There are two main blending process schemes. The first scheme called inline-blending which apply at fuel depots that have involved new gantry system (NGS) within as shown in Figure 2. The second scheme called on-tank truck blending which apply at fuel depots that have not involved NGS yet as shown in Figure 3. 


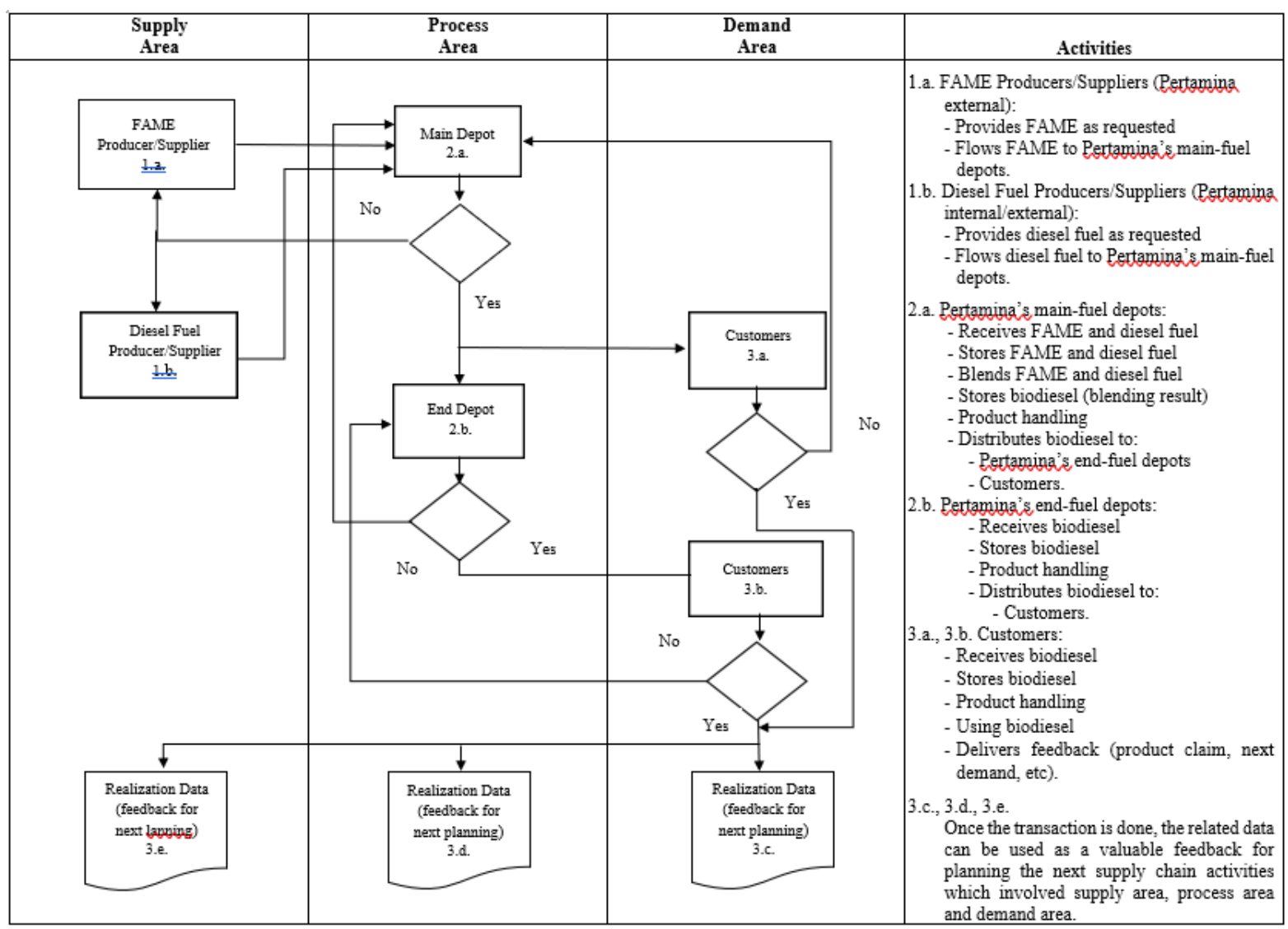

Source: Interviews (2018)

Figure 1 Biodiesel downstream supply chain in the company

Inline-blending process starts with the FAME and diesel fuel supply from each product storage tanks. FAME and diesel fuel each flow to line-pipe (inline-blending) facilities through pumping units. Both FAME and diesel fuel then blended within line-pipe (inline-blending) facilities. The blended FAME and diesel fuel (biodiesel) flow to biodiesel storage tanks through pumping units. Based on customer demand, the biodiesel delivered to customers via such appropriate product transport modes. The biodiesel dispatched to customers by fuel tank trucks and other appropriate fuel transport modes. Those related data of product supply chain activities will be derived as valuable feedback for the next supply and distribution activities. The flow of process as describe in Figure 2.

The main differences between these NGS and Non NGS operation schemes are on their level of automation and level of direct human touch. The differences will lead to their specific supply chain characteristics and risk priorities. Within the NGS scheme, there will be more automated operation and less human intervention. The Non NGS scheme faces the opposite one. The supply chain characteristics and risks of both schemes will be differentiated accordingly.

On-tank truck blending process starts with the FAME and diesel fuel supply from each product storage tanks. FAME flow to FAME filling shed units. Diesel fuel flow to diesel fuel filling shed units. Both flow through pumping units. Both FAME and diesel fuel then blended within line-pipe (inline-blending) facilities. The blended FAME and diesel fuel (biodiesel) flow to biodiesel storage tanks through pumping units. Based on customer demand, the biodiesel delivered to customers via such appropriate product transport modes. Tank trucks moves to FAME filling shed units. FAME filling shed units fills the FAME into tank trucks. Then, the FAME filled tank trucks moves to diesel fuel filling shed units to get filled with diesel fuel. Both FAME and diesel fuel already filled in tank trucks. Both blended within the tank trucks. The biodiesel (blended FAME and diesel fuel) filled tank trucks then departs from fuel depot to deliver biodiesel to customers. The biodiesel dispatched to customers by fuel tank trucks. Those related data of product supply and distribution activities will be derived as valuable feedback for the next supply and distribution activities. The flow of process as describe in Figure 3. 


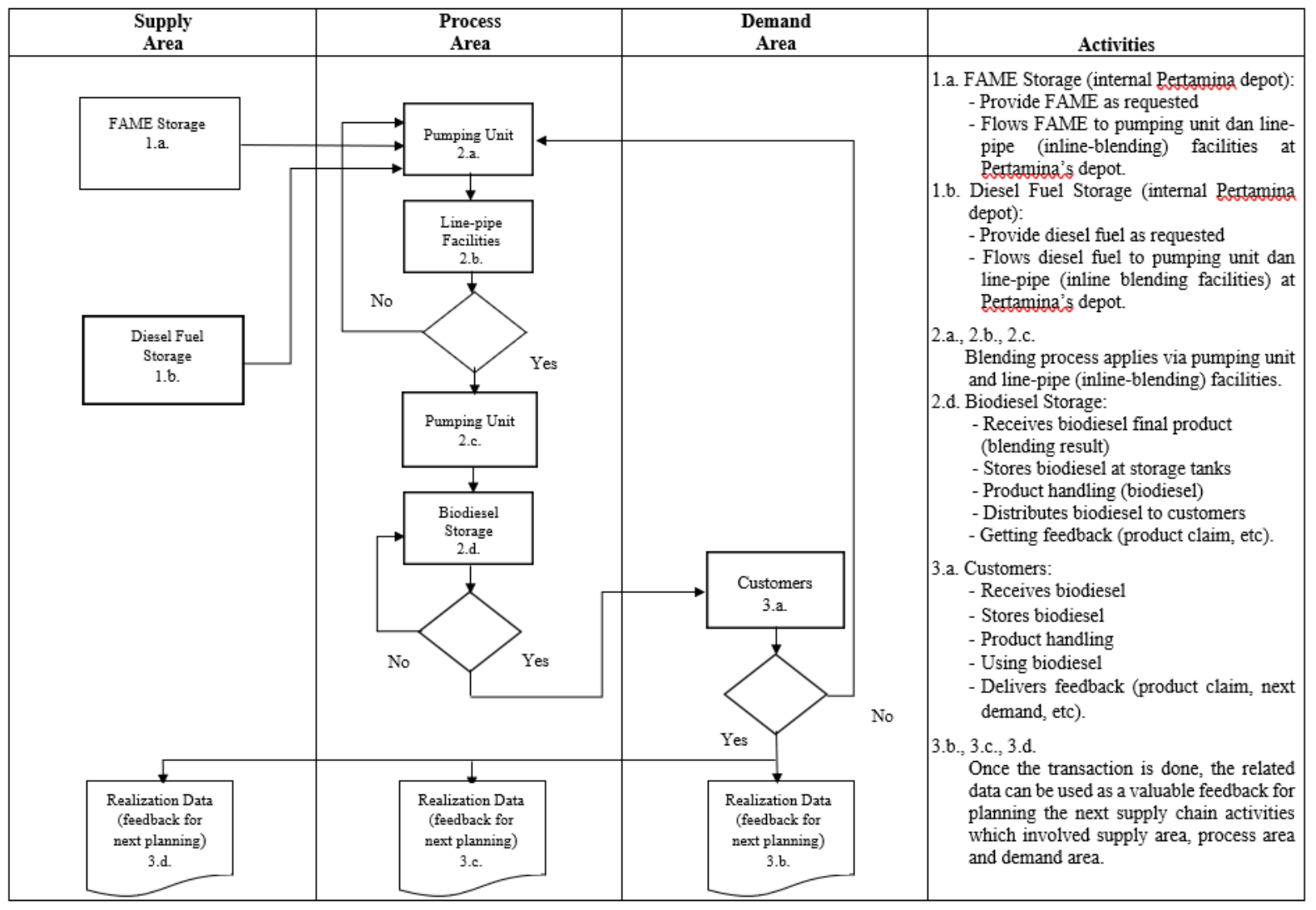

Source: Interviews (2018)

Figure 2 Biodiesel inline-blending process at NGS based fuel depot

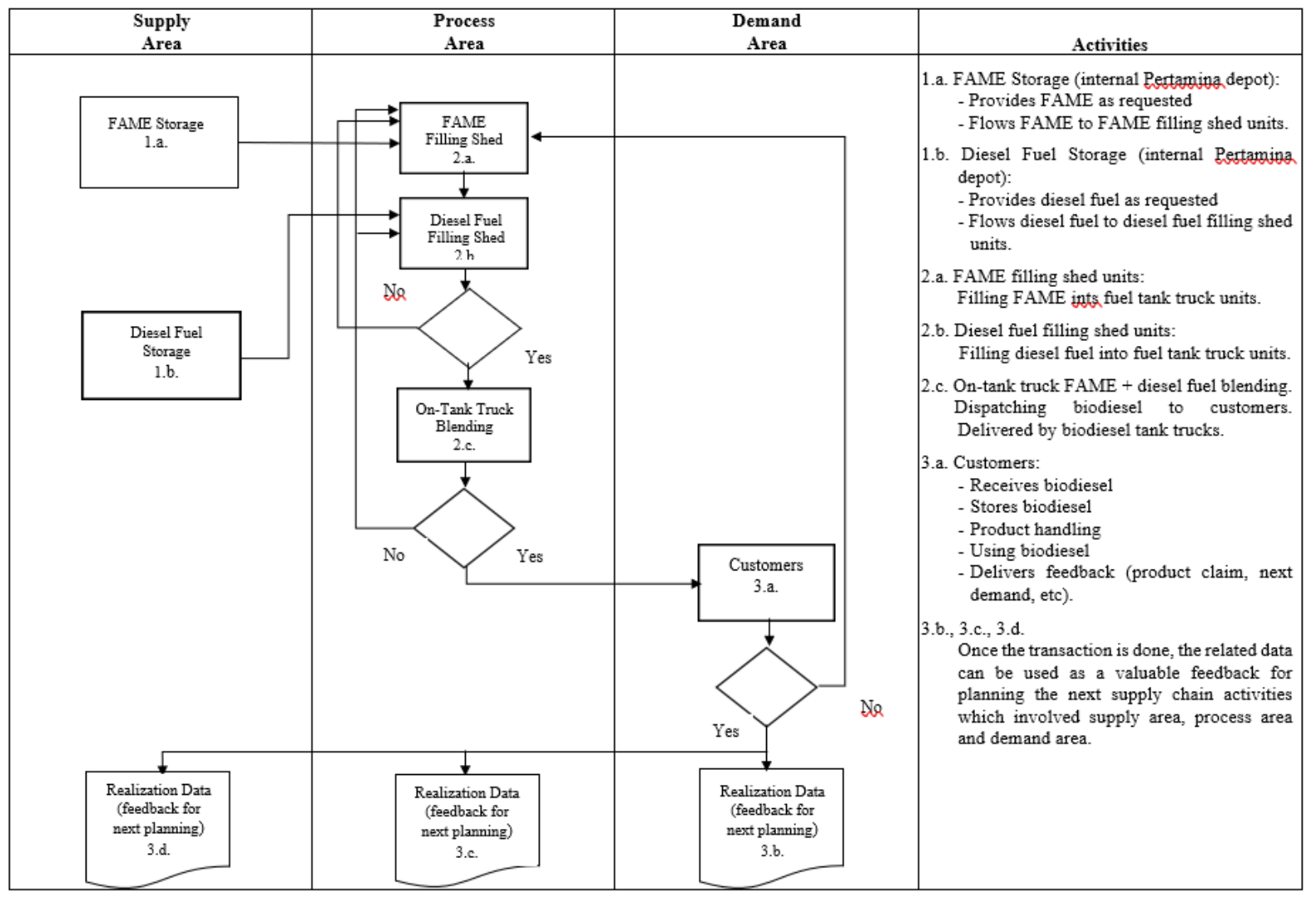

Source: Interviews (2018)

Figure 3 Biodiesel blending process at Non-NGS based fuel depot 
With refer to the energy security framework, the company's biodiesel supply chain concerned points includes: availability, accessibility, affordability dan sustainability of the product. Biodiesel supply chain related risk types includes: demand risk, process risk and supply risk. Demand risks defined as risks caused by unpredictable or misunderstood customer or end-customer demand. Process risks defined as risks caused by disruptions of internal operations or processes. Supply risks defined as risks caused by any interruptions to the flow of product, whether raw material or parts, within the supply chain.

\section{Risk Identification}

This step is to identify potential inherent supply chain risks. It includes recognizing all related risks within. The data sources consist of both primary and secondary data which derived from the expert interviews and the historical data of the target company. Table 3 shows the list of identified risk types and descriptions.

Table 3 Identified risk types and descriptions

\begin{tabular}{cc} 
Type of Risks & Description of Risks \\
\hline
\end{tabular}

\section{Demand Risks}

Demand forecast inacuracy risk

Risks caused by demand forecast inacuracy

Customer lower product knowledge and higher resistance risk Risks caused by external customer requirement fluctuation

Customer requirements variation challenges risk

Risks caused by internal customer requirement miss-management

\section{Process Risks}

Product quality \& quantity discrepancy risk

Product shortage and stock out risk

Product supply and distribution priority overlap risk

Terminal facilities availability and reliability unfit risk

Transport facilities availability and reliability unfit risk

Hazard risk

\section{Supply Risks}

Product quality and quantity discrepancy risk

Product acquisition price unfit risk

Product arrival schedule unfit risk

Product supply sustainability challenges risk

Regulation challlenges risk
Risks caused by product quality \& quantity discrepancies

Risks caused by product inventory level insuficiency

Risks caused by product supply \& distribution routing \& scheduling miss-match

Risks caused by terminal facilities unfit in availability and or reliability

Risks caused by transport facilities unfit in availability and or reliability

Risks caused by unexpected events which raised hazard (i.e: fatality, oil spill, etc)

Source: Interviews (2018)

\section{Risk Scoring}

This step is to score, calculate and analyze all identified and collected data. RPN score is calculated for each identified risk. The step also includes risk mitigation development and framework. Table 4 and Table 5 shows the identified, calculated and validated risk scores list of each biodiesel supply chain related stakeholder and location.

Table 4 List of risk scores

\begin{tabular}{|c|c|c|c|c|c|c|c|c|c|c|c|c|c|c|c|c|c|c|c|c|c|c|c|c|c|c|c|}
\hline \multirow{3}{*}{ Risk Types } & \multicolumn{9}{|c|}{ Probability } & \multicolumn{9}{|c|}{ Severity } & \multicolumn{9}{|c|}{ Detection } \\
\hline & \multirow{2}{*}{$\begin{array}{c}\text { Direktur } \\
\text { H.O. }\end{array}$} & \multirow{2}{*}{$\begin{array}{c}\text { VP } \\
\text { H.O. }\end{array}$} & \multirow{2}{*}{$\begin{array}{c}\text { Manager } \\
\text { Region }\end{array}$} & \multicolumn{6}{|c|}{ Fuel Terminal } & \multirow{2}{*}{$\begin{array}{c}\text { Director } \\
\text { H.O. }\end{array}$} & \multirow{2}{*}{$\begin{array}{c}\text { VP } \\
\text { H.O. }\end{array}$} & \multirow{2}{*}{$\begin{array}{c}\text { Manager } \\
\text { Region }\end{array}$} & \multicolumn{6}{|c|}{ Fuel Terminal } & \multirow{2}{*}{$\begin{array}{c}\text { Director } \\
\text { H.O. }\end{array}$} & \multirow{2}{*}{$\begin{array}{c}\text { VP } \\
\text { H.O. }\end{array}$} & \multirow{2}{*}{$\begin{array}{c}\text { Manager } \\
\text { Region }\end{array}$} & \multicolumn{6}{|c|}{ Fuel Terminal } \\
\hline & & & & 1 & 2 & 3 & 4 & 5 & 6 & & & & 12 & 2 & 3 & 4 & 5 & 6 & & & & 1 & 2 & 3 & 4 & 5 & \\
\hline \multicolumn{28}{|l|}{ Demand Risks } \\
\hline Demand forecast inacuracy risk & 2 & 4 & 1 & 1 & 6 & 4 & 1 & 2 & 2 & 4 & 4 & 1 & 3 & 4 & 4 & 2 & 4 & 2 & 3 & 4 & 1 & 4 & 4 & 4 & 2 & 3 & \\
\hline Customer lower product knowledge and higher resistance risk & 4 & 2 & 6 & 1 & 5 & 3 & 1 & 3 & 3 & 4 & 3 & 2 & 23 & 3 & 3 & 2 & 3 & 2 & 3 & 3 & 2 & 2 & 3 & 2 & 3 & 4 & \\
\hline Customer requirements variation challenges risk & 2 & 2 & 6 & 1 & 5 & 4 & 2 & 1 & 1 & 4 & 2 & 2 & 2 & 4 & 3 & 3 & 2 & 2 & 4 & 2 & 2 & 2 & 4 & 3 & 3 & 4 & 3 \\
\hline \multicolumn{28}{|l|}{ Process Risks } \\
\hline Product quality \& quantity discrepancy risk & 3 & 3 & 2 & 1 & 4 & 2 & 2 & 3 & 1 & 3 & 4 & 2 & 2 & 4 & 3 & 3 & 4 & 4 & 3 & 3 & 2 & 2 & 3 & 2 & 3 & 3 & \\
\hline Product shortage and stock out risk & 4 & 5 & 2 & 2 & 5 & 4 & 2 & 3 & 2 & 4 & 4 & 3 & 2 & 4 & 5 & 4 & 5 & 3 & 3 & 3 & 2 & 2 & 4 & 4 & 3 & 3 & 3 \\
\hline Product supply and distribution priority overlap risk & 4 & 5 & 3 & 4 & 5 & 2 & 2 & 3 & 3 & 4 & 4 & 3 & 4 & 4 & 3 & 4 & 3 & 3 & 3 & 3 & 2 & 4 & 4 & 3 & 4 & 3 & 3 \\
\hline Terminal facilities availability and reliability unfit risk & 4 & 5 & 5 & 1 & 5 & 2 & 1 & 3 & 1 & 4 & 4 & 4 & 4 & 4 & 3 & 2 & 5 & 3 & 3 & 3 & 2 & 2 & 4 & 2 & 3 & 4 & 2 \\
\hline Transport facilities availability and reliability unfit risk & 4 & 5 & 5 & 1 & 1 & 4 & 6 & 3 & 3 & 4 & 4 & 4 & 42 & 2 & 5 & 3 & 5 & 4 & 3 & 3 & 2 & 2 & 2 & 3 & 4 & 3 & 4 \\
\hline Hazard risk & 2 & 1 & 1 & 1 & 2 & 5 & 3 & 3 & 3 & 4 & 4 & 2 & 42 & 2 & 4 & 5 & 5 & 3 & 3 & 4 & 2 & 4 & 3 & 2 & 4 & 3 & 3 \\
\hline \multicolumn{28}{|l|}{ Supply Risks } \\
\hline Product quality and quantity discrepancy risk & 4 & 1 & 1 & 1 & 5 & 4 & 2 & 3 & 3 & 4 & 4 & 2 & 4 & 4 & 5 & 3 & 4 & 4 & 3 & 3 & 2 & 3 & 3 & 3 & 3 & 1 & 3 \\
\hline Product acquisition price unfit risk & $\mathrm{NA}$ & $\mathrm{NA}$ & 2 & NA & 5 & 4 & 1 & 3 & 1 & $\mathrm{NA}$ & $\mathrm{NA}$ & 2 & NA & 4 & 3 & 3 & 4 & 3 & $\mathrm{NA}$ & $\mathrm{NA}$ & 2 & NA & 3 & 4 & 3 & 3 & 3 \\
\hline Product arrival schedule unfit risk & 4 & 4 & 1 & 5 & 4 & 4 & 3 & 2 & 2 & 4 & 4 & 2 & 4 & 4 & 5 & 4 & 5 & 4 & 3 & 3 & 3 & 3 & 3 & 4 & 4 & 3 & 3 \\
\hline Product supply sustainability challenges risk & 4 & 4 & 1 & 2 & 3 & 3 & 3 & 2 & 1 & 5 & 4 & 2 & 4 & 4 & 5 & 4 & 5 & 4 & 3 & 3 & 4 & 3 & 4 & 4 & 4 & 3 & 3 \\
\hline Regulation challlenges risk & 6 & 6 & 6 & 5 & 5 & 2 & 3 & 3 & 2 & 3 & 4 & 4 & 4 & 4 & 4 & 4 & 4 & 3 & 4 & 3 & 2 & 2 & 3 & 5 & 4 & 5 & 3 \\
\hline
\end{tabular}

Source: Interviews (2018) 
Table 5 List of validated risk scores

\begin{tabular}{|c|c|c|c|c|c|}
\hline Risk Types & Probability & Severity & Detection & RPN & RSV \\
\hline \multicolumn{6}{|l|}{ Demand Risks } \\
\hline Demand forecast inacuracy risk & 2 & 4 & 4 & 32 & 8 \\
\hline Customer lower product knowledge and higher resistance risk & 3 & 3 & 3 & 27 & 9 \\
\hline Customer requirements variation challenges risk & 2 & 2 & 3 & 12 & 4 \\
\hline \multicolumn{6}{|l|}{ Process Risks } \\
\hline Product quality \& quantity discrepancy risk & 2 & 4 & 3 & 24 & 8 \\
\hline Product shortage and stock out risk & 3 & 4 & 3 & 36 & 12 \\
\hline Product supply and distribution priority overlap risk & 3 & 4 & 3 & 36 & 12 \\
\hline Terminal facilities availability and reliability unfit risk & 2 & 3 & 3 & 18 & 6 \\
\hline Transport facilities availability and reliability unfit risk & 4 & 4 & 3 & 48 & 16 \\
\hline Hazard risk & 1 & 4 & 3 & 12 & 4 \\
\hline \multicolumn{6}{|l|}{ Supply Risks } \\
\hline Product quality and quantity discrepancy risk & 1 & 4 & 3 & 12 & 4 \\
\hline Product acquisition price unfit risk & 3 & 3 & 3 & 27 & 9 \\
\hline Product arrival schedule unfit risk & 4 & 4 & 3 & 48 & 16 \\
\hline Product supply sustainability challenges risk & 3 & 4 & 4 & 48 & 12 \\
\hline Regulation challlenges risk & 6 & 4 & 3 & 72 & 24 \\
\hline
\end{tabular}

Source: Interviews (2018)

Figure 4 shows the risk concern differences among stakeholder levels and locations. The higher levels of stakeholder have more concern on supply risks as their priority risks. The lower level stakeholders and locations have more concern on process risks as their priority risks. Those proves that the level of stakeholder, location and level of information among stakeholders have a real correlation with the perception of risks among them.

\begin{tabular}{|c|c|c|c|c|c|c|c|c|c|}
\hline \multirow[b]{2}{*}{ Risk Types } & \multirow{2}{*}{$\begin{array}{c}\text { Visionary } \\
\text { Leader } \\
\text { at } \\
\text { Head Office }\end{array}$} & \multirow{2}{*}{$\begin{array}{c}\text { Strategic } \\
\text { Leader } \\
\text { at } \\
\text { Head Office }\end{array}$} & \multirow{2}{*}{$\begin{array}{c}\text { Operational } \\
\text { Leader } \\
\text { at } \\
\text { Region }\end{array}$} & \multicolumn{6}{|c|}{ Operation Leader at Operation Sites } \\
\hline & & & & $\begin{array}{c}\text { Fuel } \\
\text { Terminal } \\
1+2\end{array}$ & $\begin{array}{c}\text { Fuel } \\
\text { Terminal } \\
3\end{array}$ & $\begin{array}{c}\text { Fuel } \\
\text { Terminal } \\
4\end{array}$ & $\begin{array}{c}\text { Fuel } \\
\text { Terminal } \\
5\end{array}$ & $\begin{array}{c}\text { Fuel } \\
\text { Terminal } \\
6+7\end{array}$ & $\begin{array}{c}\text { Fuel } \\
\text { Terminal } \\
8\end{array}$ \\
\hline
\end{tabular}

Demand Risks

Demand forecast inacuracy risk

Customer lower product knowledge and higher resistance risk

Customer requirements variation challenges risk

rrocess misks

Product quality \& quantity discrepancy risk

Product shortage and stock out risk

Product supply and distribution priority overlap risk

Terminal facilities availability and reliability unfit risk

Transport facilities availability and reliability unfit risk

Hazard risk

suppry nisns

Product quality and quantity discrepancy risk

Product acquisition price unfit risk

Product arrival schedule unfit risk

Product supply sustainability challenges risk

Regulation challlenges risk

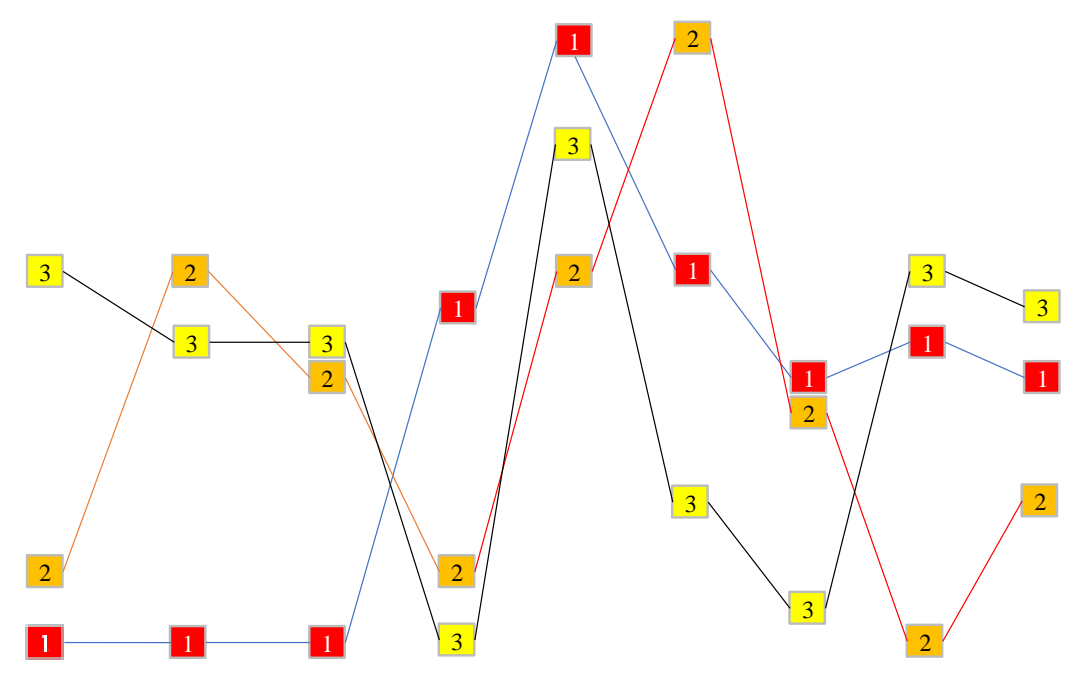

Source: Interviews (2018)

Figure 4 Stakeholder and location-based supply chain risk priorities

The higher levels of stakeholder percept priority risks as any risk which related to conceptual capabilities, such as the areas of: supply chain policy and planning. The lower levels of stakeholder percept priority risks as any risk which related to technical and or operational capabilities, such as: infrastructure availabilities and reliabilities. Those have high relevance with the level of capabilities of each level of their leadership levels. 


\section{Risk Validation}

This step is to validate the identified risks, calculation results and planned mitigation alternatives. Researcher does re-interview to the all same interviewed experts to validate those results, findings and mitigation planning. A feasibility testing will be applied to the results, including the mitigation plan.

Once the related risks identified and assessed, risk and risk mitigation priorities gained. Each of the ranked risks hast to mitigate using a specific strategy. Based on the results we may resume that regulation risk, supply arrival (delays) risk and transport facilities risk are arise as three highest biodiesel supply chain risks of the target company. Each of risk has its specific mitigation strategy.

\section{Resumes}

With refer to the research results and findings, we may resume some related insights within. The first, there are several main actors within the biodiesel supply chain activities and risk management. Actors may define as all related and critical stakeholder within the supply chain. The higher the level of actors the more conceptual related risks perceive by them. The lower level of actors the more technical and operational risks perceived by them. The higher levels of actors prefer to put their risk appetite mostly in the supply risk types. They perceive supply risks have higher priorities compares with both process risks and demand risks. This fact is relevant to what agency theory and asymmetric information theory stated for. There are issues of interest and information differences that may be affected the mentioned risk perception. In the other side, the higher levels of actors prefer to put their risk appetite mostly in the process risk types.

The second, there are several main factors involved and affected the supply chain. As above mentioned, there are elements of energy security framework, such as availability, accessibility, affordability and sustainability which the target company aim to fulfill through its supply chain area of activities. To fulfill those targets, there will be some concerned points such as developing and providing the fittest policy and implementation of raw material and final product sourcing, inventories, infrastructures, technologies, and financing. It is not only a matter of number or quantity scale fulfillment, but it is a matter of quality fulfillment, such as reliability of infrastructures and the quality of product, the capability of human resources and other related scales.

The third, those mentioned actors and factors related to the biodiesel supply chain management and activities must be re-formulate to develop risk mitigation strategies. Table 6 below offers several related mitigation strategies.

Table 6 Risk mitigation strategy alternatives for company's biodiesel supply chain

\begin{tabular}{|c|c|c|}
\hline Risk Types & Risk Descriptions & Mitigation Strategy Alternatives \\
\hline \multirow[t]{3}{*}{ Demand Risks } & Demand forecast inacuracy risk & $\begin{array}{l}\text { Intensifying collaborative planning with customers and } \\
\text { suppliers }\end{array}$ \\
\hline & Customer lower product knowledge and higher resistance risk & Intensifying customer care system \\
\hline & Customer requirements variation challenges risk & Intensifying customer care system \\
\hline \multirow[t]{6}{*}{ Process Risks } & Product quality \& quantity discrepancy risk & Intensifying quality \& quantity management system \\
\hline & Product shortage and stock out risk & $\begin{array}{l}\text { Intensifying inventory management system, product } \\
\text { consignment, supplier held stock, etc }\end{array}$ \\
\hline & Product supply and distribution priority overlap risk & $\begin{array}{l}\text { Intensifying service level agreement among related parties or } \\
\text { functions }\end{array}$ \\
\hline & Terminal facilities availability and reliability unfit risk & Intensifying facility management system \\
\hline & Transport facilities availability and reliability unfit risk & Intensifying facility management system \\
\hline & Hazard risk & Intensifying safety management system \\
\hline \multirow[t]{5}{*}{ Supply Risks } & Product quality and quantity discrepancy risk & Intensifying quality \& quantity management system \\
\hline & Product acquisition price unfit risk & Adding more suppliers, generate alternative sources \\
\hline & Product arrival schedule unfit risk & $\begin{array}{l}\text { Intensifying service level agreement among related parties or } \\
\text { functions }\end{array}$ \\
\hline & Product supply sustainability challenges risk & $\begin{array}{l}\text { Maintaining inventory at the optimum level, decentralizing } \\
\text { inventory resources }\end{array}$ \\
\hline & Regulation challlenges risk & Complying the operation to the regulation \\
\hline
\end{tabular}

Source: Author (2018)

The offered strategy alternatives are mostly proposed collaborative strategy schemes. Those will be a potential room for enhancement through future research within the similar fields.

\section{CONCLUSION AND RECOMMENDATION}

Supply chain will always be surrounded by related inherent risks. Companies must take initiatives in finding the best way to map and analyze potential risks. Since we believe that the related stakeholder levels of position, levels of information and their work locations are strategic parts of keys success factors for ensuring the effectivity and the sustainability of the 
company's supply chain management and activities, there is no choice for the company instead of stay keeping in touch with them through the best way the company can manage.

By implementing a proactive and comprehensive approach to work with company's suppliers and customers to define a strategy based on shared business goals, the company will reduce its exposure to risk and the catastrophic impact it can have. The best-laid strategies require company's team to shift their mind-set and divide their attention equally between cost-reduction efforts and risk mitigation considerations. The rewards are well worth the effort.

The proposed collaborative strategies can be applied in a vary ways. There still be some potential future research areas to study. Once the fittest strategy identified and implemented, we believe on its potential to lower related supply chain costs and higher related supply chain activities effectivity. At the end, those effort may enhance the supply chain risk management effectivity and sustainability optimistically.

\section{REFERENCES}

- $\quad$ Anggara RA. 2009. The development of risk mitigation framework in supply chain risk management. Case Study: biofuel company in Indonesia [thesis]. Manchester (UK): University of Manchester.

- $\quad$ Aprobi. 2016. Industri biodiesel Indonesia.

- Aven T. 2015. Risk analysis. Second Edition. Norway: University of Stavanger.

- Bowman J. 2015. Strategies for mitigating supply chain disruptions [disertation]. Minneapolis (US): Walden University.

- $\quad$ BPDP Kelapa Sawit. 2016. Biodiesel Indonesia.

- $\quad$ [EBTK] Direktorat Jenderal Energi Baru Terbarukan dan Konversi Energi, Kementerian ESDM. 2015. Buku Statistik EBTKE 2015

- Ghadge A, Dani S, Kalawsky R. 2012. Supply chain risk management: present and future scope. International Journal of Logistics Management. 23(3):313-339.

- Jüttner U. 2005. Supply chain risk management: understanding the business requirements from a practitioner perspective. International Journal of Logistics Management. 16(1):120-141.

- Jüttner U, Peck H, Christopher M. 2003. Supply chain risk management: outlining an agenda for future research. International Journal of Logistics: Research \& Applications. 6(4):197-210.

- Mack O, Khare A, Kramer A, Burgartz T. 2016. Managing in a VUCA world. Switzerland: Springer International Publishing.

- Manuj I, Mentzer JT. 2008. Global supply chain risk management strategies. International Journal of Physical Distribution \& Logistics Management. 38(3):192-223.

- Nadram SS, Bindlish PK. 2017. Managing VUCA through integrative self-management. Sitzerland: Springer International Publishing AG.

- Packowski J. 2014. LEAN supply chain planning-the new supply chain management paradigm for process industries to master today's VUCA world. Boca Raton (FL): CRC Press, Taylor \& Francis Group LLC.

- Peng M, Peng Y, Chen H. 2014. Post-seismic supply chain risk management: a system dynamics disruption analysis approach for inventory and logistics planning. Computers \& Operations Research. doi:http://dx.doi.org/10.1016/j.cor. 2013.03.003. 